\title{
Spatial distribution and structure of benthic macroinvertebrates in an artificial reservoir: Taabo Lake (Côte d'Ivoire)
}

\author{
Dramane DIOMANDE ${ }^{1 *}$, Natty Nattoye KPAI ${ }^{1}$, Kouakou Norbert KOUADIO ${ }^{1}$, \\ Kouassi Sébastino DA COSTA ${ }^{1,2}$ and Germain GOURENE ${ }^{1}$ \\ ${ }^{1}$ Laboratoire d'Environnement et de Biologie Aquatique, Université d'Abobo-Adjamé, \\ 02 BP 801 Abidjan 02, Côte d'Ivoire. \\ ${ }^{2}$ Centre National de Recherche Agronomique, Programme de Pêche et Aquaculture Continentale, \\ 08 BP 33 Abidjan 08, Côte d'Ivoire. \\ *Corresponding author,_E-mail: diom_dram@yahoo.fr; Tel: (225) 05702587
}

\begin{abstract}
Taabo Lake is facing eutrophication process characterized by a permanent and continuous colonization of its water body by invasive aquatic macrophytes since 1990. Until now, there is limited knowledge of its ecological state. The purpose of this study is to examine the spatial distribution and structure of benthic macroinvertebrates in Taabo Lake. Benthic macroinvertebrates were sampled from July 2006 to June 2007 using an Ekman grab. Four sampling stations were selected on the area of the reservoir along a longitudinal gradient: Sahoua and Ahondo in the upper part; Taabo Cité and Taabo Village in the lower part. Overall, 29 taxa belonging to 17 families, 7 orders and 3 classes were recorded. A total of 4028 individuals were collected. Insecta $(53.21 \%)$ were most represented, followed by Gasteropoda (36.15\%) and Oligochaeta (10.64\%). A better knowledge of the ecological traits of species and the identification of indicator taxa will permit to develop a Benthic Quality Index able to monitor the lakes and man-made reservoirs of Côte d'Ivoire.

(C) 2013 International Formulae Group. All rights reserved.
\end{abstract}

Keywords: Benthic macroinvertebrates, diversity, structure, lake, Côte d'Ivoire.

\section{INTRODUCTION}

The hydroelectric dams, whose essential role is the production of electricity, contribute not only to the water supply of the population, but also support agricultural activities and fishing. The artificial reservoirs generated by these hydropower dams provide many valuable economic services to the bordering populations mainly though their halieutic resources. However, the availability of halieutic resources of these aquatic systems is threatened because of overexploitation of stocks and pollution (Camargo et al., 2005; Conley et al., 2009).

Taabo Lake is particularly facing eutrophication characterized by a permanent and continuous colonization of its water body by invasive aquatic macrophytes since 1990 (Kouassi, 2007). This situation, generally caused by an enrichment of the reservoir with nutrients and pesticides coming from surrounding agricultural areas, threatens aquatic living resources in terms of availability, diversity and structure (Bonada et

(C) 2013 International Formulae Group. All rights reserved. DOI : http://dx.doi.org/10.4314/ijbcs.v7i4.7 
al., 2006; Roche and Tidou, 2009). Taabo Lake is a major source of water supply for domestic and agricultural purposes in the region. Subsistence agriculture and human settlement are the main types of land use around the reservoir which stands as an essential halieutic resource for the local populations and the inhabitants of Abidjan as well (Tidou, 2009). Due to its crucial importance on a local scale, this ecosystem must be well-managed. To reach this objective and for the conservation of freshwater resources in Taabo Lake, the understanding of the ecological structure and function of the various biological communities is a prior step. Indeed, the distribution of organisms relative to their habitat is of central importance in ecology. Nanami et al. (2005) reported that the nature of this distribution provides information on the types of ecological processes that regulate settlements and assemblages. This makes it possible to understand the complex dependency of one compartment on the others. In aquatic ecosystems, the benthic compartment is the most sensitive zone because it receives all particles contained in the water body by sedimentation (Arienzo et al., 2001).

Therefore, benthic communities are increasingly studied (Tumwesigye et al., 2000; Ndaruga et al., 2004; Camara et al., 2012). They are commonly used as indicator of ecological disturbance (Lewis et al., 2001; Piedras et al., 2006) due to their sensitivity to environmental changes and easiness of sampling. Benthic macroinvertebrates are crucial to the functioning of aquatic ecosystems according to their role in nutrient recycling (Devine and Vanni, 2002; Edia et al., 2007) and their importance as essential food-web components that link primary production to fisheries (Diomandé et al., 2001; Tachet et al., 2003; Kouamélan et al., 2006).

Despite their functions described above, there are few reports on the benthic macroinvertebrates living in freshwater ecosystems of Côte d'Ivoire (Diomandé and Gourène, 2005; Edia et al., 2007; Camara et al., 2012). Concerning Taabo Lake, only the works of Kouamé et al. (2010) and kouamé et al. (2011) exist. These papers dealt with macroinvertebrates associated to macrophyte habitats. The present study, carried out in order to increase our knowledge on the structure and functioning of Taabo Lake, propose to (1) describe the composition of benthic macroinvertebrates and (2) analyse the spatial distribution and structure of these organisms.

\section{MATERIALS AND METHODS}

\section{Study area}

The present study was carried out on Taabo Lake, a man-made reservoir in Côte d'Ivoire (West Africa). Located on the Bandama River between $5^{\circ} 07^{\prime} \mathrm{W}$ and $6^{\circ} 40^{\prime} \mathrm{N}$, the reservoir extends on $69 \mathrm{~km}^{2}$ with $26 \%$ of its water area covered by invasive macrophytes (Figure 1). It is a major source of water supply for domestic and agricultural purposes. Subsistence agriculture and human settlement are the main types of land use around the reservoir which stands as an essential halieutic resource for the local populations and the inhabitants of Abidjan as well (Tidou, 2009). Its catchment area is roughly $58700 \mathrm{~km}^{2}$. The maximum water depth is $3.4 \mathrm{~m}$. The climate is tropical and humid with a mean annual temperature of $28.2{ }^{\circ} \mathrm{C}$, whereas the mean annual precipitation is $1101.5 \mathrm{~mm}$ (Kouassi et al., 2007).

\section{Sampling design}

Samples were collected in Taabo Lake from July 2006 to June 2007 at four sites following a longitudinal gradient (Figure 1): the stations of Sahoua and Ahondo were located in the upper part of the reservoir and those of Taabo Village and Taabo Cité in the lower part. At each station, four campaigns were conducted during the sampling period. They were carried out in July and December 
2006, March and June in 2007. Five sediment samples were collected by station using an Ekman grab $($ area $=15 \times 15 \mathrm{~cm})$ and sieved in situ by a $1 \mathrm{~mm}$ mesh. The material retained on the mesh was fixed in 5\% formol solution. In the laboratory, the macroinvertebrates were sorted and identified at the lowest taxonomic level possible using appropriate literature (Dejoux et al., 1981; Diomandé et al., 2000 and Tachet et al., 2003). Oligochaeta had not been identified beyond of class owing to the lack of keys.

For each campaign, sediment sampling was coupled with in situ measurements of physical and chemical parameters including temperature, hydrogen-ion concentration $(\mathrm{pH})$, electric conductivity, dissolved oxygen $\left(\mathrm{O}_{2}\right)$ and turbidity. Water turbidity was recorded using a turbidimeter AQUA LYTIC while the other parameters were recorded with a multi-parameter analyser WTW 340i.

\section{Data analysis}

The macroinvertebrate structure was described through abundance, density (individuals $/ \mathrm{m}^{2}$ ) and three alpha diversity measure, including species richness $R$ (number of taxa), Shannon diversity index $\left(H^{\prime}\right)$ and Piélou evenness index $(E)$. A beta diversity index was applied in order to evaluate the taxonomic similarity between the four stations defined. We applied Whittaker index $(\beta \mathrm{w})$ to all pairs of sites, calculated as: $\beta \mathrm{w}=\left(\mathrm{Sr} / \alpha_{\text {mean }}\right)-1$, where $\mathrm{Sr}$ is the total richness in each site and $\alpha_{\text {mean }}$ the mean richness across both sites. Significant differences in abiotic parameters, densities, Shannon diversity index $\left(H^{\prime}\right)$ and Piélou evenness index $(E)$ between stations were performed using a Kruskal-Wallis test followed by multiple comparison ranks (Camara et al., 2012). Before performing these comparison tests, the normality of data was checked by the Kolmogorov-Smirnov test ( $p>0.05$ at all stations). Analyses were carried out using the software package Statistica version 7.1. A significance level of $p<0.05$ was considered.

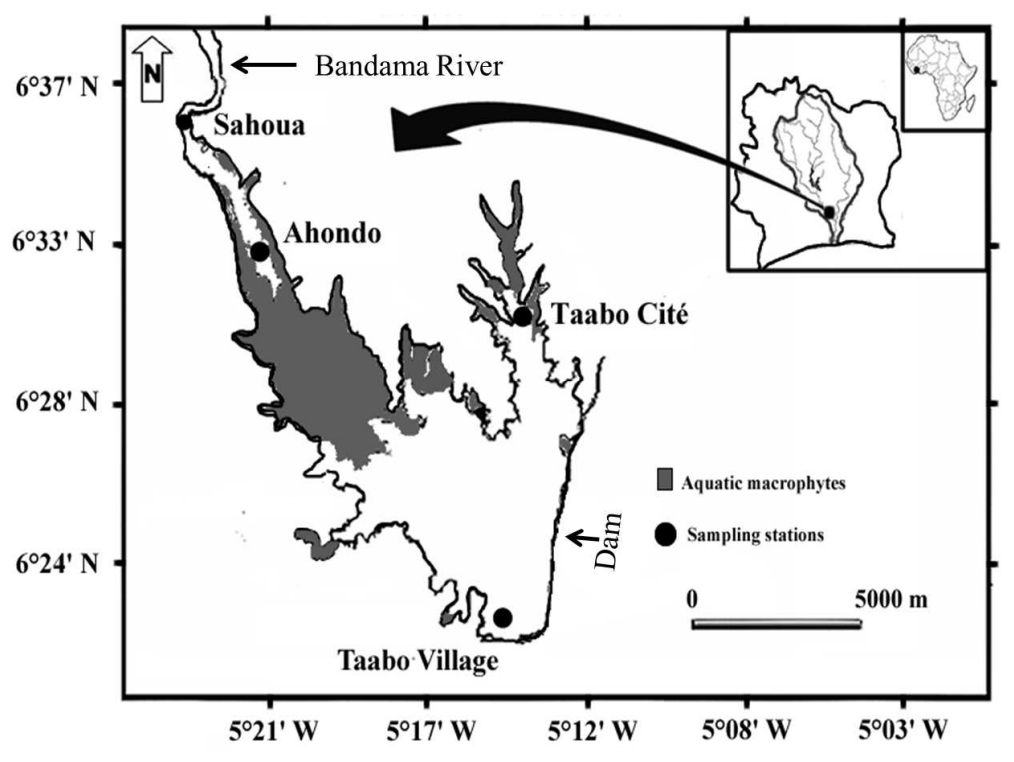

Figure 1: Location of sampling stations used in the benthic community survey at Taabo Lake. 


\section{RESULTS}

Abiotic parameters

Table 1 presents the values of environmental variables of Taabo Lake. Only turbidity was significantly different between the stations (Kruskal-Wallis test; $p<0.05$ ). Stations Taabo Village (9.81 NTU) and Taabo Cité (13.85 NTU) recorded the lowest values of turbidity, while the highest values were observed at stations Ahondo (15.60 NTU) and Sahoua (16.15 NTU). Temperature varied from $27.2{ }^{\circ} \mathrm{C}$ (Sahoua) to $30.10{ }^{\circ} \mathrm{C}$ (Taabo Cité). pH in Taabo Lake varied from 6.93 to 7.29. In Taabo Lake, conductivity varied from $65 \mu \mathrm{S} . \mathrm{cm}^{-1}$ to $119 \mu \mathrm{S} . \mathrm{cm}^{-1}$ (Sahoua). The lowest dissolved oxygen value $\left(3.40 \mathrm{mg} . \mathrm{L}^{-1}\right)$ was observed at station Sahoua and the highest value (8.66 mg. $\left.\mathrm{L}^{-1}\right)$ was found at station Taabo Cité.

\section{Taxonomic composition}

A total of 29 benthic macroinvertebrates taxa belonging to 17 families, 7 orders and 3 classes (Gastropoda, Insecta, Oligochaeta) were identified during this study (Table 2). The richest class was Insecta (24 taxa) followed by Gastropoda (4 taxa). Oligochaeta were considered as 1 taxon. The class of Gastropoda includes 4 species divided into 3 families all belonging to the order of Mesogastropoda. These species (Cleopatra bulimoides, Melanoides tuberculata, Lanistes varicus and Bulinus globosus) were only found at Taabo Cité and Taabo Village. Insecta was represented by 6 orders: Ephemeroptera, Trichoptera, Heteroptera, Odonata, Coleoptera and Diptera. This last order is the most diversified with 10 taxa belonging to 4 families (Ceratopogonidae, Chaoboridae, Chironomidae and Culicidae). Among these families, Chironomidae were the most diversified with 6 taxa: Ablabesmyia sp., Chironomus sp., Cricotopus sp., Stenochironomus sp., Polypedilum sp. and Tanytarsus sp.. In addition, these species were common to all the study sites.
The analysis of the taxonomic richness showed that Taabo Cité is most diversified (17 taxa), followed by Sahoua (15 taxa) and Ahondo (13 taxa). Taabo Village had the lowest taxonomic richness (10 taxa). The low values of $\beta_{\mathrm{W}}$ were observed for the pairs of stations Ahondo-Sahoua (0.38) and AhondoTaabo Cité (0.41) while highest values were obtained for the pairs Taabo Cité-Taabo Village (0.58), Sahoua-Taabo Cité (0.62), Ahondo-Taabo Village (0.71) and SahouaTaabo Village (0.81).

\section{Spatial assemblage structures}

Throughout the survey period, 4028 individuals including 2088 at Taabo Cité, 1412 at Taabo Village, 400 at Ahondo and 128 at Sahoua were collected. Insecta, Gastropoda, and Oligochaeta represented respectively, $53.21 \%, 36.15 \%$ and $10.64 \%$ of the sampled individuals. Melanoides tuberculata, Chironomus sp. and Polypedilum sp. were the most dominant species and were especially found at Taabo Cité and Taabo Village (Figure 2). At both stations, the densities of sampled Gastropoda, ranged from 920 to $4660 \mathrm{ind} / \mathrm{m}^{2}$ and from 880 to 2450 ind $/ \mathrm{m}^{2}$ respectively (Figure 3). Ahondo showed the highest densities of Oligochaeta (144 to $2270 \mathrm{ind} / \mathrm{m}^{2}$ ). The highest densities of Insecta were recorded at Taabo Cité (from 33 to $11800 \mathrm{ind} / \mathrm{m}^{2}$ ) and Taabo Village (from 335 to $7800 \mathrm{ind} / \mathrm{m}^{2}$ ). Kruskal-Wallis test revealed a significant variation of the macroinvertebrates densities between sites ( $p$ $<0.05)$.

The Shannon index respectively reached high and low values at Sahoua (2.15) and Ahondo (0.42). As for the evenness, the highest value was obtained at Sahoua station (0.86) and weakest at Taabo Cité (0.33). At Sahoua, the Shannon index and evenness vary from 0.8 to 2.15 and from 0.6 to 0.86 respectively. These indices did not differ significantly among stations (Kruskal-Wallis test, $p>0.05$ ). 


\section{DISCUSSION}

The difference of turbidity observed between the sites may be explained by the water velocity. The dam alters water flow and enhances sedimentation rate (Palmer et al., 2000; Kouassi et al., 2007). This situation may lead to the weaker values of turbidity at Taabo Cité and Taabo Village.

The settlement of collected benthic macroinvertebrates includes 29 taxa divided into 17 families, 7 orders and 3 classes. Taabo Lake taxonomic richness was lower than that obtained by Diomandé and Gourène (2005) in Lake Ayamé I (Côte d'Ivoire) but showed higher densities of macroinvertebrates. That suggests a great availability of benthic trophic resources in this reservoir. In terms of diversity, Kouamé et al. (2010) and Kouamé et al. (2011) found 68 and 43 taxa of macroinvertebrates respectively. They worked on the macroinvertebrates associated to macrophyte habitats. Their results showed the importance of macrophyte habitats on macroinvertebrates taxonomic diversity. Indeed, these habitats are used by the macroinvertebrates as food resource, shelter against predators and for reproduction (Murphy and Giller, 2000; Jesus, 2006).

Globally, the composition of the settlement (Oligochaeta, Gastropoda and Insecta) corresponds to that generally encountered in freshwater sediments (Kabré et al., 2002; Diomandé and Gourène, 2005). According to Pointier et al. (2004), the low specific richness of Gastropoda is typical to the malacological fauna of tropical freshwaters which is relatively impoverished, compared to marine or terrestrial fauna. Insecta were found at all stations and represent the most diversified class with 24 taxa. The insects colonize all the aquatic environments owing to their dispersal capacity with strong preference for freshwaters (Tachet et al., 2003).

Collected in a large amount, Gastropoda and Insecta seem to meet better ecological conditions in the lower part of the reservoir (lacustrine zone). Melanoides tuberculata within Gastropoda is an invasive species which may cause the displacement of the planorbid Biomphalaria (Pointier and Jourdane, 2000). The insect densities recorded at Taabo Cité and Taabo Village are mainly dominated by Chironomidae (Chironomussp. and Polypedilum sp.). Leonard and Ferrington (2007) mentioned that Chironomidae are big consumers of algae. The high densities at Taabo Cité and Taabo Village let us suppose that these sites are characterized by an important development of algae. According to Ouattara et al. (2001), stagnant waters promote algae reproduction and development so that the Chironomidae of both zones found enough algae to fulfil their foodneed. As for Oligochaeta, it is a sediment-dwelling organism which primarily feeds on detritus (Tachet et al., 2003). So, their abundance observed at Ahondo station might be related to the substrate nature, which is characterized by the presence of mud and macrophytes rests. The substrate nature is of importance in benthic macroinvertebrates distribution (Camara et al., 2012). The taxonomic richness is maximum at Taabo Cité (presence of macrophyte, detritus throughout the year) and minimal at Taabo Village (sandy substrate). At Taabo Village the tidal range varies considerably, throughout the year because of the hydropower functioning and topography. Then the macrophytes at this site often become riparian vegetation after water edge receding causing insects settlement instability. Moreover, the beta diversity index $(\beta w)$ presents a low value at these stations (0.38). 
(a)

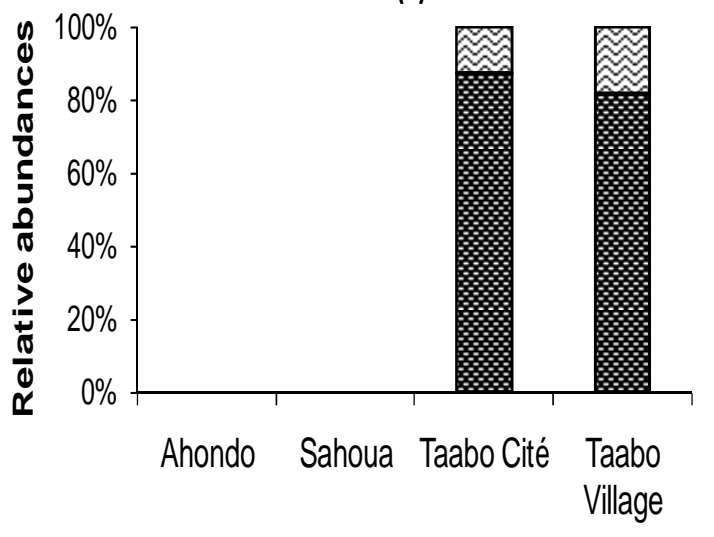

(b)

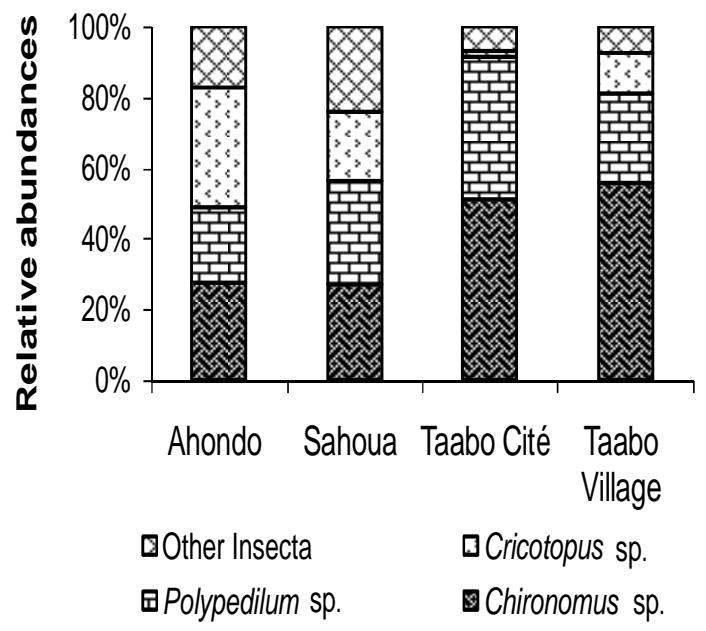

Figure 2: Relative abundance of Gastropod (a) and Insect (b) species found at the four study sites.
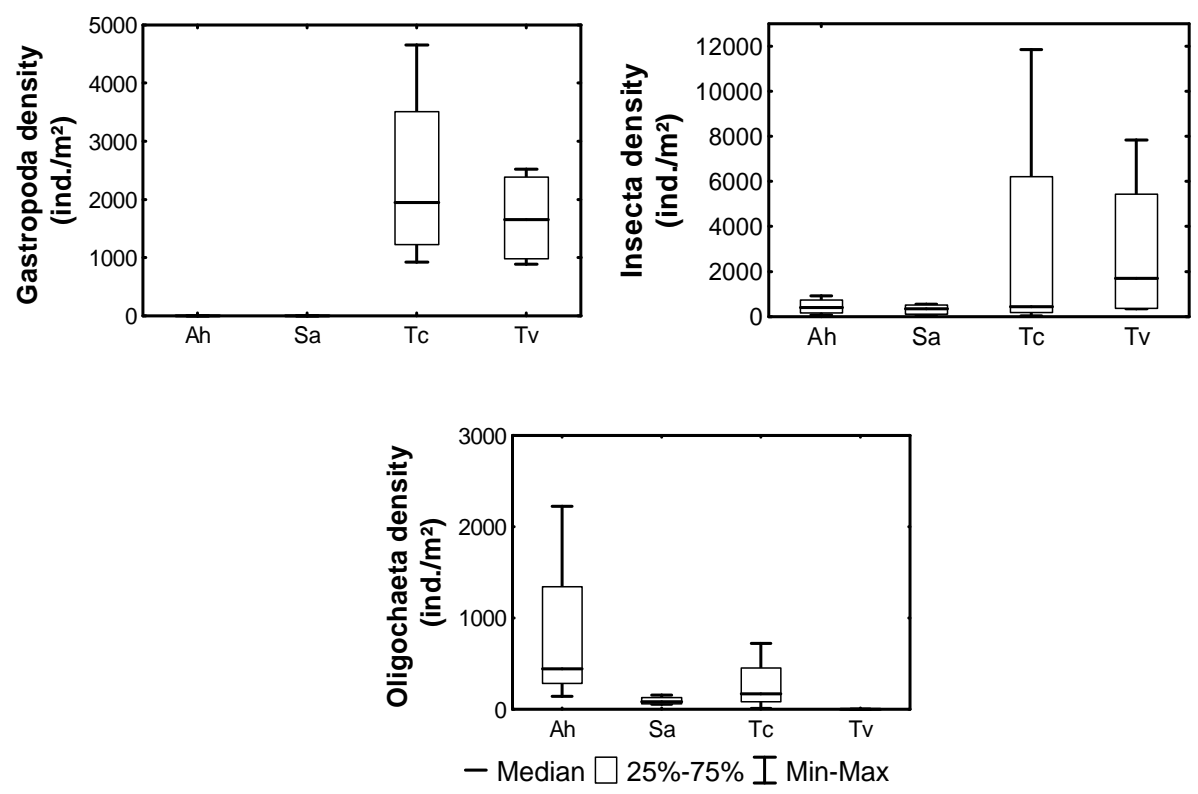

Figure 3: Box plots showing the variation of the densities of benthic macroinvertebrates at the four study sites (Ah: Ahondo; Sa: Sahoua; Tc: Taabo Cité; Tv: Taabo Village). 
Table 1: Water physico-chemical parameters of studied stations in Taabo Lake.

\begin{tabular}{|c|c|c|c|c|c|c|c|c|c|c|c|c|c|}
\hline \multirow{2}{*}{ Parameters } & \multicolumn{3}{|c|}{ Sahoua } & \multicolumn{3}{|c|}{ Ahondo } & \multicolumn{3}{|c|}{ TaaboCité } & \multicolumn{3}{|c|}{ TaaboVillage } & \multirow{2}{*}{$\begin{array}{l}\text { Kruskal-Wallis test } \\
\text { (p values) }\end{array}$} \\
\hline & Median & Min & Max & Median & Min & Max & Median & Min & Max & Median & Min & Max & \\
\hline $\begin{array}{l}\text { Temperature } \\
\left({ }^{\circ} \mathrm{C}\right)\end{array}$ & 28.15 & 27.20 & 30.01 & 28.25 & 27.60 & 29.60 & 28.95 & 28.60 & 29.60 & 28.70 & 28.50 & 29.20 & 0.770 \\
\hline $\mathrm{pH}$ & 7.11 & 5.71 & 7.29 & 7.12 & 4.75 & 7.62 & 7.29 & 6.76 & 7.58 & 6.93 & 6.75 & 7.11 & 0.441 \\
\hline Turbidity (NTU) & 16.15 & 13.20 & 25.00 & 15.60 & 11.40 & 21.00 & 13.85 & 12.50 & 16.09 & 9.81 & 9.04 & 10.90 & $\mathbf{0 . 0 3 3} *$ \\
\hline $\begin{array}{l}\text { Conductivity } \\
(\mu \mathrm{S} / \mathrm{cm})\end{array}$ & 81.70 & 65.00 & 119.00 & 81.70 & 65.60 & 111.00 & 85.50 & 78.00 & 105.50 & 88.00 & 70.00 & 98.70 & 0.930 \\
\hline $\begin{array}{l}\text { Dissolved } \\
\text { Oxygen }\left(\mathrm{mg} . \mathrm{L}^{-1}\right)\end{array}$ & 4.97 & 3.40 & 5.70 & 4.93 & 3.50 & 6.00 & 5.26 & 4.40 & 8.66 & 5.20 & 4.30 & 5.84 & 0.701 \\
\hline
\end{tabular}


D. DIOMANDE et al. /Int. J. Biol. Chem. Sci. 7(4): 1503-1514, 2013

Table 2: Taxonomic list of benthic macroinvertebrates found at the four study sites in Taabo Lake.

\begin{tabular}{|c|c|c|c|c|c|c|c|}
\hline \multirow[b]{2}{*}{ Class } & \multirow[b]{2}{*}{ Order } & \multirow[b]{2}{*}{ Family } & \multirow[b]{2}{*}{ Taxon } & \multicolumn{4}{|c|}{ Stations } \\
\hline & & & & Ahondo & Sahoua & Taabo Cité & Taabo Village \\
\hline \multirow{4}{*}{ Gastropoda } & Mesogastropoda & Planorbidae & Bulinusglobosus & & & $*$ & \\
\hline & & Ampulariidae & Lanistesvaricus & & & $*$ & $*$ \\
\hline & & Thiaridae & Cleopatra bulimoides & & & $*$ & $*$ \\
\hline & & & Melanoidestuberculata & & & $*$ & $*$ \\
\hline \multirow[t]{14}{*}{ Insecta } & Ephemeroptera & Baetidae & Cloeonsp. & $*$ & $*$ & & $*$ \\
\hline & & Caenidae & Caenis sp. & $*$ & & $*$ & \\
\hline & & Leptophlebiidae & Choroterpessp. & $*$ & $*$ & & \\
\hline & Odonata & Gomphidae & Paragomphus sp. & $*$ & & $*$ & \\
\hline & & Libellulidae & Olpogastrasp. & & & & $*$ \\
\hline & Heteroptera & Belostomidae & Diplonychussp. & $*$ & $*$ & & \\
\hline & & Ranatridae & Ranatralinearis & & $*$ & & \\
\hline & Coleoptera & Dytiscidae & Hydrovatus sp. & & & $*$ & \\
\hline & & & Hydaticussp. & & $*$ & $*$ & \\
\hline & & & Hydaticusussheri & & & $*$ & \\
\hline & & Elmidae & Dupophilus sp. & & $*$ & & $*$ \\
\hline & & & Riolussp. & & $*$ & & \\
\hline & Trichoptera & Leptoceridae & Leptocerussp. & & $*$ & & \\
\hline & & & Oecetissp. & $*$ & & $*$ & \\
\hline
\end{tabular}


D. DIOMANDE et al. / Int. J. Biol. Chem. Sci. 7(4): 1503-1514, 2013

\begin{tabular}{|c|c|c|c|c|c|c|c|}
\hline & & & Parasetodessp. & $*$ & * & & \\
\hline & Diptera & Ceratopogonidae & Ceratopogon sp. & $*$ & * & $*$ & \\
\hline & & Chaoboridae & Chaoborussp. & & $*$ & & \\
\hline & & Chironomidae & Ablabesmyiasp. & $*$ & & $*$ & $*$ \\
\hline & & & Chironomus sp. & $*$ & $*$ & $*$ & \\
\hline & & & Cricotopussp. & $*$ & & & $*$ \\
\hline & & & Polypedilum sp. & $*$ & $*$ & $*$ & \\
\hline & & & Stenochironomussp. & & $*$ & $*$ & $*$ \\
\hline & & & Tanytarsussp. & & & & $*$ \\
\hline & & Culicidae & Culexsp. & & & $*$ & \\
\hline Oligochaeta & unspecified & Unspecified & unspecified & $*$ & $*$ & $*$ & \\
\hline TOTAL & 7 & 17 & 29 & 13 & 15 & 17 & 10 \\
\hline
\end{tabular}


This value indicates a high turnover between both stations otherwise the taxonomic similarity between them could result of various facts. Note that the taxonomic richness of Sahoua and Ahondo is largely due to the insects. They hold a dispersal ability allowing them to move from a station to another nearby (Sites et al., 2003). Moreover, the water flow at Sahoua station could facilitate the downstream drift of insects to Ahondo (Shearer et al., 2002). Indeed, the substrates of these study stations present a similar composition (vegetable remains, sand and mud). This could also explain the taxonomic similarity observed because substrate constitutes the living environment of the benthic organisms. The quantitative analysis of the settlement revealed the prevalence of as a result of competition for habitat and food. Dajoz (2000) reported that evenness values tending towards 0 indicate an unbalanced following the growth of a limited number of species. With regard to the variations of Shannon diversity and evenness indices, the highest values obtained at station Sahoua showed that macroinvertebrates assemblage collected at this station are more diversified and well structured than the other stations.

\section{Conclusion}

This study allowed us to identify 29 taxa of benthic macroinvertebates in Taabo Lake dominated by Insecta and Gastropoda. Insecta and Gastropoda occurred mainly in the lacustrine zone of the reservoir, where turbidity is low due to strong sedimentation. However, further investigation should be performed in order to have an insight about the temporal variation of macroinvertebrates assemblages following a seasonal scale. The identification of indicator taxa is needed to develop a Benthic Quality Index able to monitor the lakes and man-made reservoirs of Côte d'Ivoire.

\section{ACKNOWLEDGEMENTS}

This study has been realized according to the Project Challenge Programme FIS/CGIAR/COMSTECH N ${ }^{\circ}$ A/4007-1 of the Centre National de Recherche Agronomique (CNRA). We are grateful to the International Foundation for Science (IFS: Sctockholm) and, the Committee on Scientific and Technological Cooperation of the Organisation of Islamic Conference (Islamabad; Pakistan) for providing financial support to perform the present study.

\section{REFERENCES}

Arienzo M, Adamo P, Bianco MR, Violante P. 2001. Impact of land use and urban runoff on the contamination of the Sarno River Basin in Southern Italy. Water Air Soil Poll., 131: 349-366.

Bonada N, Prat N, Resh V, Statzner B. 2006. Development in aquatic insects biomonitoring: A comparative analysis of recent Approaches. Annu. Rev. Entomol., 51: 495-523.

Bony KY. 2007. Biodiversité et écologie des Mollusques Gastéropodes d'eau douce en milieu continental ivoirien (Bassin de l'Agnebi, de la Mé et du Banco). Trait d'histoire de vie d'une espèce invasive Indoplanorbis exustus (Deshayes, 1834). Thèse de Doctorat. Ecole Pratique des Hautes Etudes, Paris, France, 217pp.

Burgmer T, Hillebrand $\mathrm{H}$, Pfenninger $\mathrm{M}$. 2007. Effects of climate-driven temperature changes on the diversity of freshwater macroinvertebrates. Oecologia, 151: 93 - 103.

Camara AI, Diomandé D, Bony YK, Ouattara A, Franquet E,Gourène G. 2012. Diversity assessment of benthic macroinvertebrate communities in Banco National Park (Banco Stream, Côte d'Ivoire). Afr. J.Ecol., 50: 205-217.

Camargo JA, Alonso A, De la Puente M. 2005. Eutrophication downstream from small reservoirs in mountain rivers of 
Central Spain. Water. Res., 39: 33763384.

Conley DJ, Pearl HW, Boesch DF, Seitzinger SP, Havens KE, Lancelot C, Likens GE. 2009. Ecology: Controlling Eutrophication: Nitrogen and Phosphorous. Science, 323: 1014-1015.

Dajoz R. 2000. Précis d'Ecologie (7 $\left.{ }^{\mathrm{ème}} \mathrm{edn}\right)$. Dunod : Paris, France ; 615p.

Dejoux C, Elouard JM, Forge P Maslin JL. 1981. Catalogue Iconographique des Insectes de Côte d'Ivoire. ORSTOM. Bouaké, Côte d'Ivoire ; 127p.

Devine JA, Vanni MJ. 2002. Spatial and seasonal variation in nutrient excretion by benthic invertebrates in a eutrophic reservoir. Freshw. Biol., 47: 1107-1121.

Diomandé D, Gourène G. 2005. Premières données sur la macrofaune benthique de l'hydrosystème fluvio-lacustre de la Bia (Côte d'Ivoire). Sci. Nat., 2 : 167 - 176.

Diomandé D, Gourène G, Tito de Morais L. 2001. Stratégie alimentaire de Synodontisbastiani (Suliriformes : Mochokidae) dans le système fluviolacustre de la Bia (Côte d'Ivoire). Cybium, 25: 7 - 21 .

Edia OE, Brosse S, Ouattarra A, Gourène G, Winterton P, Lek-Ang S. 2007. Aquatic insect assemblage patterns in four WestAfrican coastal rivers. J. Biol. Sci., 7: 1130-1138

Jesus T. 2006. The influence of substrate composition in benthic macroinvertebrate communities of the Alva River, Portugal. International Association of Theoretical and Applied Limnology, 29 : 1722 - 1724.

Johnson RK, Wiederholm T, Rosenberg DM, 1993. Freshwater biomonitoring using individual organisms, populations, and species assemblages of benthic macroinvertebrates. In Freshwater Biomonitoring and Benthic Macroinvertebrates, Rosenberg DM,
ReshVH, (eds). Chapman and Hall: New York, USA; 40-158.

Kabré TA, Diguingué D, Bouda S. 2002. Effet du rétrécissement de la superficie d'eau sur les macroinvertébrés benthiques du lac de barrage de la Comoé, Sud-Ouest du Burkina Faso. Sci. Tech., Sci. Nat. Agro., 26: 37 - 49.

Kouamé MK, Diétoa MY, Edia OE,Da Costa SK, Ouattarra A, Gourène G. 2011. Macroinvertebrate communities associated with macrophyte habitats in tropical man-made lake (Lake Taabo, Côte d'Ivoire). Knowl. Manag. Aquat. Ec., 400(03): 1-18.

Kouamé MK, Diétoa MY, Da Costa SK, Edia OE, Ouattarra A, Gourène G. 2010. Aquatic macroinvertebrate assemblages associated with root masses of water Hyacinths, Eichhornia crassipes (Mart.) Solms-Laubach, 1883 (Commelinales: Pontederiaceae) in Taabo Lake, Ivory Coast. J. Nat. Hist., 44: 257-278.

Kouamélan EP, Koné, N'Douba V, Ollevier F. 2006. Food habit and trophic resource partitioning among three mormyrid fishes from man-made Lake Ayamé, Ivory Cost. Afr. Zool., 41: 266 - 274.

Kouassi KL, Goné DL, Meledje NH, Wognin AVI, Aka K. 2007. Hydrologie et évolution spatio-temporelle des charges solides en suspension dans le lac du barrage hydroélectrique de Taabo (Côte d'Ivoire). Eur. J. Sci. Res., 18 : 465 478.

Leonardo C, Ferrington J. 2007. Global diversity of non-biting midges (Chironomidae; Insecta-Diptera) in freshwater. Hydrobiologia, 595: 447455.

Lewis PA, Klemm DJ, Thoeny WT. 2001. Perspectives on the use of multimetric lake bioassement integrity index using benthic macroinvertebrates. Northeast. Nat., 8: 233 - 246. 
Murphy FJ, Giller SP. 2000. Seasonal dynamics of macroinvertebrates assemblages in the benthos and associated with detritus packs in two low-order streams with different riparian vegetation. Freshw. Biol., 43: 617 - 631.

Ndaruga AM, George GN, Gichuki NN, Wamicha WN. 2004. Impact of water quality on macroinvertebrates assemblages along a tropical stream in Kenya. Afri. J. Ecol., 42 : 208 - 216.

Ouattara A, Podoor N, Gourène G. 2001. Etudes préliminaires de la distribution spatiotemporelle du phytoplancton dans un système fluvio-lacustre africain (Basin Bia ; Côte d'Ivoire). Hydroécol. Appl., 13(1): 113-132.

Paul JF, Scott KJ, Campbell DE, Gentil JH, Stroble CS, Valente RM, Weisberg SB, Holland AF, Ranasinghe JA. 2001. Developing and applying a benthic index of estuarine condition for the Virginian Biogeographic Province. Ecol. Indicators, 1: 83 - 99.

Pointier JP, Jourdane J. 2000. Biological control of the snail hosts of schistosomiasis in an area of low transmission: the example of the Caribbean area. Acta Trop., 77: 53 - 60.
Pointier JP, Facon B, Jarne P, David P. 2004. Les thiaridés, des Gastéropodes envahisseurs des eaux douces tropicales. Xenophora, 104: $14-20$.

Roche H, Tidou A. 2009. First Ecotoxicological Assessment Assay in a Hydroelectric Reservoir: The Lake Taabo (Côte d'Ivoire). Bull. Environ. Contam. Toxicol., 82: 322 - 326.

Shearer KA, Hayes JW, Stark JD. 2002. Temporal and spatial quantification of aquatic invertebrate drift in the Maruia River, South Island, New Zealand. N. Z. J. Mar. Freshw. Res., 36: 529 - 536.

Sites RW, Willig MR, Linit MJ. 2003. Macroecology of aquatic insects: a quantitative analysis of taxonomic richness and composition in the Andes Mountains of Northern Ecuador. Biotropica, 35: 226 - 239.

Tachet H, Bournaud M, Richoux PH. 2003. Invertébrés d'Eau Douce. Systematique, Biologie, Ecologie. Editions CNRS: Paris, France ; 587p.

Tumiwesigye C, Yusuf SK, Makanga B. 2000. Structure and composition of benthic macroinvertebrates of a tropical forest stream, River Nyamweru, western Uganda. Afri. J. Ecol., 38: 72-77 